\title{
Comparison between Group Discussion Flipped Classroom and Lecture on Student Achievement and Student Characters
}

\section{Putu Sudarmika}

Learning Technology Study Program, Ganesha University of Education, Indonesia, sudarmika_sanglah@yahoo.co.id

I Wayan Santyasa

Ganesha University of Education, Indonesia, santyasa@yahoo.com

\section{Dewa Gede Hendra Divayana}

Ganesha University of Education, Indonesia, hendra.divayana@undiksha.ac.id

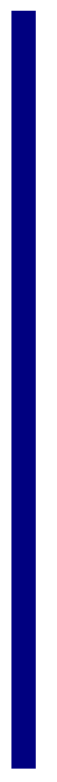

\begin{abstract}
Higher education has aim to prepare students before they live in social life of community. The purpose of this study was determining difference student achievement and student character between group discussion flipped classroom (GDFC) and lecture learning. The population in this study consist of two classes with total sampling technique. 72 nursing students divided into two class. One class as control and the other one as treatment class. The design used form quasi experiment pre-test and post-test non-equivalent control group design. This study used two instrument an extended multiple choice and character questionnaire. Hypothesis testing is done with Mancova after followed by the normality test, homogeneity test and linearity test. The results of the study stated as follows, first there were differences in student achievement and student character between GDFC learning and lecture with a significance value of $p=0.001$. Second, there are differences in student achievement between GDFC learning and lecture with a significance value of $p=0.001$. Third, there are differences in student character between GDFC learning and lecture with a significance value of $p=0.003$. GDFC is superior in achieving learning achievement and efforts to improve character compared to lecture. GDFC can arouse the interest and desire of nursing students to learn through media that have been given before learning begins, build a culture of learning in the form of personal and interpersonal contact between students and students, between groups with groups and between students and lecturers.
\end{abstract}

Keywords: Group discussion flipped classroom, lecture, student achievement, student character, learning

Citation: Sudarmika, P., Santyasa, I. W., \& Divayana, D. G. H. (2020). Comparison between Group Discussion Flipped Classroom and Lecture on Student Achievement and Student Characters. International Journal of Instruction, 13(3), 171-186. https://doi.org/10.29333/iji.2020.13312a 


\section{INTRODUCTION}

Character education is increasing becoming focus of education. The Indonesian national education law number 20 the year 2003, chapter II, article 3 states that national education has functions to develop capabilities and shape dignified national character and civilization in order to educate the nation's life, develop potential students to become human believers and fear God Almighty, noble, healthy, knowledgeable, capable, creative, independent and become a democratic and responsible citizen. There are some problem that quite worrying of education in Indonesia such as cases of behavior and moral deviation of students wich is not accordance with the value of character and scientific attitud (Wicaksono, 2016). Good character will lead the students to have strong beliefs and motivation to compete with other people from various countries (Aristina et al., 2018). There are some news in mass media tells a lot about corruption, dishonesty and bribery among officials and also reporting health workers affected by case problem with their patients shows that education has important role in creating generations who are not only intellectually intelligent but also have positive characters. Students who are intellectually intelligent are not enough to deliver the country to a better future (Widayanti \& Hakim, 2017). Vela et al (2018) state character strength refers to thoughts, feelings and behaviors that help a person achieve personal potential and well-being. The end result of the whole learning process is students achievement. Students achievement is a testament to the success that has been achieved by students where each learning activity can cause a distinctive change. Achieving learning objectives in the form of learning achievement is the result of teaching and learning activities alone. The continuity of the learning process in school is determined by many factors that support the achievement of the expected goals. Lecture is an old method that is most widely used in medical institutions because lecture learning is easily regulated and can be effective in conveying information to many students and has the potential to simplify concepts (Daud et al., 2016; Doshi, 2017).

Learning lecture is centered learning on the teacher or lecturer. The choice of this learning method is because it allows the lecture to provide new information, which is based on the results of original research that is generally not found in the text book and lecture can dramatize important concepts based on personal views. Some conditions with lecture learning can improve student learning. Lecture can be an important supporter of affective learning when a sound lecturer makes it possible to take notes, open questions and provide opportunities to become active listeners (Titsworth, 2001). Good lecture provides material that is relevant to learning based on students' preferences, active in increasing knowledge by finding new, current and limited information in each class. All of these strategies require communication skills as the main tool to deliver material to students (Meyer \& Hunt, 2017). Mazer and Hess (2017) mention in a meta-analysis of 225 studies on the effectiveness of lecture learning methods with active learning in students finding that lectures improve learning outcomes $(55 \%)$ compared to active learning or teaching methods $(36 \%)$. Now there has been a change in learning orientation from teacher-centered learning to student centered learning and the selection of the right learning model in learning. One student-centered learning method is flipped classroom cooperative learning. Milman (2012) states that 
flipped classroom is a learning approach with the aim of learning efficiency by transferring knowledge to students through videos, vodcasts, discussion and group work during the learning process. Sams and Bergmann (2014) state that flipped classroom in a simple manner as a lesson at school is done at home and homework is done at home finished at school. During the learning process, students carry out various activities such as finding answers to questions so that they are ready before learning, doing problem solving, group work and group discussions (Formica et al., 2010; Ozdamli \& Asiksoy, 2016). Cooperative learning methods or collaborative learning have been widely applied in the world of education and are important learning conditions for educators (Stenlund et al., 2016). Slavin et al (2003) stated that a group can achieve better results compared to individuals who work alone. Learning by participating in group discussions is an important part of collaborative and cooperative learning so it is necessary to know which learning strategies are most effective, and also how individual differences can affect learning for educators and students (Stenlund et al., 2016).

Individual differences that affect learning can occur as in group discussions. Group discussion is defined as a group of individuals who gather for verbal communication with the purpose of making decisions or just sharing knowledge. In group discussions, the lecturer or teacher introduces concepts or questions to be discussed then the group analyzes the problem or performs the assigned task so that group discussions are seen in the learning context that learning can be said to succeed if the assignments can be completed well in each subject (Morgan et al., in Stenlund et al., 2016). Emergency nursing courses are courses focusing on developing knowledge, skills and attitudes by applying the concepts and principles of nursing care to patients who have actual problems or life-threatening risks that occur suddenly or unexpectedly in physical and environmental conditions that are not determined later. implemented and developed so as to prevent further disability and death (Tyas, 2016). Small group discussions are effective learning approaches in nursing education to improve student learning in theoretical knowledge and skills development (Wong, 2018). Florence (2018) states that nursing is specifically a profession that is expected to work with various health disciplines and collaborative learning approaches that have been adopted in nursing education to maximize student learning outcomes. Florence (2018) supports collaborative learning in nursing increasing academic involvement, facilitating social interaction, fostering knowledge and skills, learning attitudes, motivation and learning achievements of each individual. Moral decision making is an integral part of nursing responsibility and as one of the main goals of nursing education when nursing students enter into nursing clinical practice. When nursing students enter the real practice room, they will face a moral dilemma that can cause ethical problems as part of character values (Khatiban et al., 2018). The use of appropriate learning methods is expected to improve learning achievement and increase student character as a manifestation of national character.

\section{CONTEXT AND LITERATUR REVIEW}

This study aims to determine how the influence of flipped classroom group discussion learning on learning achievement and character of nursing students. Unal \& Unal (2017) 
involving 16 teachers and 623 students found that the flipped classroom learning model obtained higher results for learning outcomes, student perceptions and teacher satisfaction compared to traditional classes.

\section{Flipped Classroom Group Disscusion}

Flipped Classroom is an active approach that is student-centered and formed to increase the period in the class (Ozdamli \& Asiksoy, 2016). The main purpose of the flipped classroom to provide students preparation for topics that will be discussed before the learning process begins so that face-to-face learning becomes more qualified (Formica et al., 2010). Advantages in a flipped classroom approach such as, increasing interactive periods in the classroom (Fulton, 2012), provide opportunities for discussion with their teachers that they may not get in a traditional approach, supporting teams working in discussion groups in class (Milman, 2012). Nouri's research (2016) found that students preferred flipped classroom learning, especially learning material using video, flexibility in terms of time and mobility and learning felt easier and more effective. Flipped classroom is a teaching method that replaces individual learning with group learning in a dynamic interactive environment where the teacher guides students to understand the concepts. Flipped classroom involves the active participation of nursing students in learning activities both before and during classroom learning (Dehghanzadeh \& Jafaraghaie, 2018). Different results were found in the Albalawi study (2018) which stated there was no significant difference between traditional learning and flipped clasroom. Peterson's (2016) involving 43 students found that the average value of student learning achievement was higher in flipped classroom compared to traditional learning lecture.

Group discussion is one of collaborative learning. Cooperative learning is a learning approach that is oriented to social interactions, group dynamics, learning and learning processes that accommodate individual differences, social, academic and interpersonal development of students. Cooperative learning involves student participation and reduces differences between students. The need for face-to-face interaction affects group size so that the arrangement of cooperative learning should be no more than five or six members in a group (Santyasa, 2017). Collaborative learning can foster better collaborative behavior where students can criticize each other so that if lecturers can provide support, guidance and encouragement in groups they can achieve more effective learning goals (Huang et al., 2016).

\section{Lecture}

Lecturers are an important part in achieving the success of education in schools and even the state because the profession of lecturer not only teaches science but also morals, attitudes and all aspects of students that have an impact on the quality of human resources (Syah et al., 2017). In general the learning lecture is teacher centered where the teacher or lecturer brings material through a presentation and is followed by a question and answer session with a short time. Students usually become passive learners during the learning process and they will get more lessons when increasing their knowledge based on constructivism theory (Lei li, 2015). Learning methods with 
lectures are methods that are still widely used in the form of face-to-face delivery (lecturing) and tend to be in the same direction. The effectiveness of this learning pattern is lower and cannot foster active participation in the learning process. In this learning lecturer becomes the center of the role in achieving learning outcomes and becomes the only source of knowledge for students. However, this lecture method does not have to be eliminated but is still given a certain combination or percentage, for example in expert lectures or public lectures (Muhammad, 2018). Lecture usually uses slideshows (powerpoint) in presenting learning material with many information formats including text, graphics, images, sound material or ending visual information through whiteboard media. Projector and projection media are most helpful in normal classroom situations and the advantage is being able to present material in many perspectives, especially for weak instructors by reducing complications from messages and increasing abilities in accordance with the material delivered (Wright in Liu et al., 2015). Teaching in higher education requires a variety of knowledge and skills in various aspects where lecturing is a form of general teaching (Lindberg, 2018). Lecture learning is not an optimal teaching strategy in helping students learn especially in the application of treatment or scientific content for clinical scenarios and real situations (Bleske et al., 2016).

\section{Student Achievement}

The end result of the whole learning process is student achievement. Winkel (in Noviyanti, 2017) states that student achievement is a testament to the success achieved by students, where each learning activity can cause a distinctive change. Achieving learning objectives in the form of student achievement is the result of teaching and learning activities only (Noviyanti, 2017). In other words, the quality of teaching and learning activities is the only determinant of learning outcomes. In general, the learning outcomes test assesses what is obtained after the students are given a lesson. In the preparation of the test results of learning efforts are made to determine the knowledge and skills that have been taught at various levels of education and the items of the test are prepared to assess their achievements (Noviyanti, 2017).

Student achievement can also be mentioned by the level that students have in accepting, rejecting, and assessing information and understanding obtained during the learning process. Hamdani's opinion (2011) states that student achievement is obtained from an activity. Ardiansyah et al (2017) student achievement in learning evaluation is interpreted as a systematic way to state the state of the student related to cognitive, affective and psychomotor aspects which are usually indicated in scores or numbers from a number of subjects.

\section{Student Character Education}

Character education is defined by various education experts. For example Santrock (in Aly, 2017) says that character education is a direct approach to moral education by giving lessons to students about basic moral knowledge to prevent them from committing immoral behavior or harm to themselves or others. The Ministry of National Education (2010) defines a character as a person's character, character, or personality 
which is formed from the results of internalizing various virtues that are believed and used as a basis for perspective, thinking and acting. Lickona (1991) offers another definition where character education is a business that is intentionally carried out to help someone so that he can understand, pay attention and do basic ethical values (Aly, 2017). Margaret (in Karim, 2018) states character education as a national movement creates schools that foster ethics, be responsible, and nurture the younger generation by modeling and teaching good character through emphasis on universal values that we all share. In addition, there are three important components of changing behavior, namely the behavior that occurs, the behavior itself, and the consequences of behavior.

Based on the above definitions, four important things are found in character education. First, character education is the same as moral education. Second, character education aims to shape students' personalities to become good human beings and good citizens. Third, character education contains three main elements, namely knowing goodness, loving kindness and doing good. Fourth, the character of the students can be mastered by the teacher through his example, such as the way the teacher talks or delivers the material, the way the teacher tolerates, and various other related things.

The implementation of character education through the learning process in the classroom is manifested in the form of lecture learning about norms, group discussions, teacher exemplary, observations and warnings about students, sociodrama about the value of life. Julia \& Supriyadi (2018) state that teachers can be moral models and characters in schools so teachers are expected to not only teach methodology and content but also moral values. Other strategies can be done by integrating existing local community wisdom values and developing local wisdom that is full of great values into learning strategies that will enhance the positive character of students (Parwati et al., 2018).

Lickona (1991) states that in lectures at Harvard universities mentioned characters are higher than intelligence. Success will be wasteful without character qualities such as honesty, sense of responsibility, kindness, and perseverance in the face of difficulties. Character values are also shown in the ethics of nursing education (Karim et al., 2018). Boozaripour et al (2017) research states that ethical values in nursing education such as respect for others, wisdom, constructive relationships, fairness and commitment in nursing education are the main things in nursing education. Further stated that mutual respect between students and educators as a very important aspect. Integration of character values is not only the responsibility of religious education and civic education but all fields of study have the same responsibility (Hamid et al., 2018).

Character education in educational institutions aims to create 3 (three) things, namely (1) good people, (2) good schools, and (3) good people. The first goal is directed so that all humans have good character. The second goal is directed so that schools can realize good character. The third objective, states that character education is essential in building a moral society (Santyasa, 2017. 


\section{METHOD}

The design of this study used a quasi-experimental design with research design using non equivalence pre-test post-test control group design. The study was conducted in two classes. The first class is a class that is given treatment with lecture learning and the second class with flipped classroom group discusion learning. Then the two classes carried out the same measurements. The population in this study were all nursing students at the IV semester KESDAM IX Udayana Nursing Academy as many as 72 students with total sampling technique. Each class has the same opportunity as a sample. Data collection by giving pretest and questionnaires to students in the sample class to find out the initial understanding of students and initial characters. The next process is implementing the learning process for all sample class students in accordance with the learning plan that has been prepared. After learning was carried out, data collection was continued by giving posttest in the form of learning achievement tests and character questionnaires.

\section{Research Instrument}

The research instruments in this study were pretest questions, posttest and student character questionnaires that had been carried out a series of reliability and validity tests. The test used in this study took the form of an extended response multiple choice type test. The emergency nursing learning device consists of lesson plans and learning media that are evaluated by content experts and design experts, namely two lecturers who have sufficient qualifications and work experience. Validation of learning devices includes content, systematics, language structures used in learning devices. Learning tools that have been validated are revised again until they are completely valid to use. The content validity test was carried out through expert tests which were then analyzed by Gregory's formula. The instrument used in gathering student character is based on the development of the character of the 2010 Ministry of National Education with the preparation of character values adjusted to emergency nursing courses. In this study 30 items will be developed with 5 Likert scales, namely strongly agree, agree, hesitate, disagree, strongly disagree. The student character questionnaire consisted of 24 favorable statements and 6 unfavorable statements.

\section{FINDINGS}

Table 1

Descriptive of Respondents

\begin{tabular}{lll}
\hline & \multicolumn{2}{l}{ class $\mathrm{n}=72$} \\
\cline { 2 - 3 } Variable & GDFC class $\mathrm{n}=36$ & Lecture class $\mathrm{n}=36$ \\
\hline Gender $(\mathrm{n}, \%)$ & & \\
man & $11(30.6 \%)$ & $10(27.8 \%)$ \\
woman & $25(69.4 \%)$ & $26(72.2 \%)$ \\
Early student achievement (mean, SD) & $47.47 \pm 4.74$ & $45.06 \pm 6.33$ \\
Student achievement post experimen (mean, SD) & $71.08 \pm 5.66$ & $63.26 \pm 5.74$ \\
Student initial character (mean, SD) & $78.96 \pm 4.80$ & $78.35 \pm 6.57$ \\
Student character post experimen (mean, SD) & $84.50 \pm 4.44$ & $82.40 \pm 6.39$ \\
\hline
\end{tabular}


Characteristics based on sex in this study in group discussion class flipped classroom, men as many as 11 respondents $(30.6 \%)$ while women as many as 25 respondents (69.4\%). Gender in lecture class, male as many as 10 respondents (27.8\%) and women as many as 26 respondents $(72.2 \%)$. The results of the initial achievements in the class discussion flipped classroom, obtained with an average of $\mathrm{M}=47.47$; $\mathrm{SD}=4.748$, and the initial results of the lecture class are obtained with an average $\mathrm{M}=45.06 ; \mathrm{SD}=6.33$. Student achievement results after experiments on class group flipped classroom discussions, obtained with an average $\mathrm{M}=71.08 ; \mathrm{SD}=5.66$ and the results of learning achievement after the experiment class lecture obtained with $\mathrm{M}=63.26$; $\mathrm{SD}=5.740$ ). The results of the students' initial character in the group discussion flipped classroom class, obtained with an average $\mathrm{M}=78.96$; $\mathrm{SD}=4.80$ ) and the results of the initial character of students in the lecture class are obtained with an average of $\mathrm{M}=78.35$; SD $=6.57$. The results of the student character after experimenting with the class discussion flipped classroom, were obtained with an average of $\mathrm{M}=84.50 ; \mathrm{SD}=4.44$ and student character after the experiment in the lecture class were obtained with an average $\mathrm{M}=$ $82.40 ; \mathrm{SD}=6.39$. These results indicate that descriptively the learning achievements and character of students in emergency nursing courses had a significant increase between the classes taught by group discussion flipped classroom compared to the lecture.

The results of the normality test using kolmogorov-smirnov and Shapiro-wilk were obtained with a significance number of more than 0.05 (sig> 0.05) so that Ho was accepted which meant that the four groups of data in this study were normally distributed. The results of the Test of Homogeneity of Variance test showed that the significance level of the pretest learning achievement results with a significance score of 0.293 , the results of the posttest learning achievement with a significance number of 0.531 , the result of the pretest of student characters obtained a significance value of 0.070 . Data with a significance number of more than 0.05 ( $\mathrm{sig}>0.05$ ) means that the data has the same or homogeneous variance. While the posttest results of student characters were obtained with a significance level of $0.034<0.05$, which means the data did not have the same or not homogeneous variants'

The relationship between the covariate (the results of the pretest) and the dependent variable is student learning achievement obtained by the value of $F$ linearity 22.645 with p-value smaller than the value of the specified set of 0.05 , the regression coefficient is significant. The relationship between character covariates and the dependent variable, namely the student character, obtained the $\mathrm{F}$ linearity value of 12.889 with p-value smaller than the set significance value of $0.05(\mathrm{p}=0.001)$, the regression coefficient is significant. Box'M value 5.017 with a significance of 0.182 greater than 0.05 means that the variant variable matrix is the same so Manova's analysis can be continued.

Table 2 describes the F value for Pillai's Trace, Wilk Lamda, Hotelling Trace, Roy's Largest Root has a significance value smaller than 0.05 , meaning that there are differences in learning achievement and student character between group discussion flipped classroom and lecture. 
Table 2

F value for Pillai's Trace, Wilk Lamda, Hotelling Trace, Roy's Largest Root

\begin{tabular}{lllllll}
\hline Effect & & value & $\mathrm{F}$ & Hypothesis df & Error df & sig \\
\hline Intercept & Pillai's Trace & .433 & $25.568 \mathrm{~b}$ & 2.000 & 67.000 & .000 \\
& Wilks' Lambda & .567 & $25.568 \mathrm{~b}$ & 2.000 & 67.000 & .000 \\
& Hotelling's Trace & .763 & $25.568 \mathrm{~b}$ & 2.000 & 67.000 & .000 \\
& Roy's Largest Root & .763 & $25.568 \mathrm{~b}$ & 2.000 & 67.000 & .000 \\
Early & Pillai's Trace & .173 & $7.026 \mathrm{~b}$ & 2.000 & 67.000 & .002 \\
student & Wilks' Lambda & .827 & $7.026 \mathrm{~b}$ & 2.000 & 67.000 & .002 \\
achievment & Hotelling's Trace & .210 & $7.026 \mathrm{~b}$ & 2.000 & 67.000 & .002 \\
& Roy's Largest Root & .210 & $7.026 \mathrm{~b}$ & 2.000 & 67.000 & .002 \\
Early & Pillai's Trace & .152 & $6.002 \mathrm{~b}$ & 2.000 & 67.000 & .004 \\
student & Wilks' Lambda & .848 & $6.002 \mathrm{~b}$ & 2.000 & 67.000 & .004 \\
character & Hotelling's Trace & .179 & $6.002 \mathrm{~b}$ & 2.000 & 67.000 & .004 \\
& Roy's Largest Root & .179 & $6.002 \mathrm{~b}$ & 2.000 & 67.000 & .004 \\
Class & Pillai's Trace & .317 & $15.529 \mathrm{~b}$ & 2.000 & 67.000 & .000 \\
& Wilks' Lambda & .683 & $15.529 \mathrm{~b}$ & 2.000 & 67.000 & .000 \\
& Hotelling's Trace & .464 & $15.529 \mathrm{~b}$ & 2.000 & 67.000 & .000 \\
& Roy's Largest Root & .464 & $15.529 \mathrm{~b}$ & 2.000 & 67.000 & .000 \\
\hline
\end{tabular}

Table 3

Test of between-Subjects Effects

\begin{tabular}{|c|c|c|c|c|c|c|}
\hline Source & $\begin{array}{l}\text { Dependent } \\
\text { variable }\end{array}$ & $\begin{array}{l}\text { Type III sum of } \\
\text { squares }\end{array}$ & $\mathrm{df}$ & $\begin{array}{l}\text { Mean } \\
\text { square }\end{array}$ & $\mathrm{F}$ & Sig. \\
\hline \multirow{3}{*}{$\begin{array}{l}\text { Corrected } \\
\text { model }\end{array}$} & Posttes & $1482.391 \mathrm{a}$ & 3 & 494.130 & 17.733 & .000 \\
\hline & $\begin{array}{l}\text { character post } \\
\text { experimen }\end{array}$ & $405.465 b$ & 3 & 135.155 & 5.115 & .003 \\
\hline & posttest & 585.914 & 1 & 585.914 & 21.027 & .000 \\
\hline \multirow[t]{2}{*}{ Intercept } & $\begin{array}{l}\text { caharater post } \\
\text { experimen }\end{array}$ & 728.182 & 1 & 728.182 & 27.556 & .000 \\
\hline & posttest & 378.682 & 1 & 378.682 & 13.590 & .000 \\
\hline Pretest & $\begin{array}{l}\text { character post } \\
\text { experimen }\end{array}$ & 8.926 & 1 & 8.926 & .338 & .563 \\
\hline \multirow{3}{*}{$\begin{array}{l}\text { Initial } \\
\text { character }\end{array}$} & posttest & 1.244 & 1 & 1.244 & .045 & .833 \\
\hline & $\begin{array}{l}\text { character post } \\
\text { experimen }\end{array}$ & 316.940 & 1 & 316.940 & 11.994 & .001 \\
\hline & posttest & 795.163 & 1 & 795.163 & 28.536 & .000 \\
\hline Class & $\begin{array}{l}\text { character post } \\
\text { experimen }\end{array}$ & 50.338 & 1 & 50.338 & 1.905 & .172 \\
\hline
\end{tabular}

Table 3 describes the test of between effects effects of learning achievement listed in the results showing $F$ value 17.733 with a significance of 0.000 smaller than 0.05 , which means there are differences in learning achievement between group learning discussion on flipped classroom with lecture. The second part of the corrected model is obtained by the student character with a value of F 5.115 and a significance value of 0.003 smaller than the significance value set at 0.05 means that there is a significant difference from the student character between group discussion flipped classroom with lecture. 


\section{DISCUSSION}

The learning process aims to achieve defined learning objectives effectively and efficiently by using various media and learning methods as a means of learning. The learning process of emergency nursing courses is oriented towards the achievement of the ability to think critically, systematically and comprehensively in carrying out the concept of emergency and emergency through a nursing care approach as the foundation in solving problems.

This causes students to be required to be more active in the learning process. Lecturers are expected to have the ability to provide interactive learning media, prepare and make learning strategies more attractive. The fact that students have not been able to improve their abilities and express their ideas of knowledge in emergency nursing courses has an impact on learning achievement, one of the reasons is learning that is still centered on lecturers. The need to change the learning process paradigm as an effort to help improve the ability of knowledge and skills possessed. Learning is not only as a process of transferring knowledge from lecturers to students but more about how lecturers provide services in the form of learning methods and strategies that help students shape their knowledge. This study examines more deeply how the differences in student learning achievement through the conventional learning strategy of the lecture compared to the group discussion flipped classroom learning strategy. Descriptive analysis results of this study indicate that student achievement through group discussion flipped classroom learning gets an average value of $\mathrm{M}=71.08$ while student learning achievements through lecture learning obtain an average value of $M=63.26$. The character of students through learning group discussion flipped classroom gets an average value of $\mathrm{M}=84.50$ while the character of students through lecture learning gets an average value of $\mathrm{M}=$ 82.40 .

The first hypothesis of the results showed that there were significant differences in learning achievement and student character between group learning discussion on flipped classroom and lecture with a significance value smaller than 0.05 . The results of this study are slightly different from the Albalawi study (2018) which states that there is no significant difference in student learning achievement between traditional learning and flipped classroom. Flipped Classroom is an active approach that is student-centered and formed to increase the period in the class (Ozdamli \& Asiksoy, 2016). Students prefer flipped classroom learning, especially learning material using video, flexibility in terms of time and mobility and learning are felt easier and more effective (Nouri, 2016). Flipped classroom involves the active participation of nursing students in learning activities both before and during classroom learning (Dehghanzadeh \& Jafaraghaie, 2018). Group discussion is one of collaborative learning that is oriented to social interactions, group dynamics, learning and learning processes that accommodate individual differences, social, academic and interpersonal development of students. Cooperative learning involves student participation and reduces differences between students (Santyasa, 2017). Research by Unal \& Unal (2017) involving 16 teachers and 623 students found that the flipped classroom learning model showed higher results for learning outcomes, student perceptions and teacher satisfaction compared to traditional 
classes. Based on the description and discussion, it can be concluded in general that group discussion classroom is far superior to lecture learning in achieving student learning achievement

The second hypothesis of this study shows that there are significant differences in learning achievement between group learning discussion on flipped classroom and lecture. Working on assignments in groups is an important component to be applied to university level education because with the assignment of tasks in groups you will get better results when compared to working alone (Pratama \& Wulanyani, 2018). Florence (2018) states that collaborative learning is effective in increasing knowledge and skills. Collaborative learning can foster better collaborative behavior where students can criticize each other so that if lecturers can provide support, guidance and encouragement in groups they can achieve more effective learning goals (Huang et al., 2016). The process of discussion and collaboration in groups can produce a lot of reflective thinking and generate new ways of thinking in achieving the goals set through reflection that are positively correlated with learning achievement (Huang et al., 2016). Based on the description of the discussion, it can be concluded that student learning achievements can be improved through group learning discussion flipped classroom with results of learning achievement that is more optimal than the learning lecture

The third hypothesis of this study shows that there are differences in student character between group discussion flipped classroom with lecture. Triatmanto (2010) mentions that education about character is a process starting from the level of understanding, habituating oneself to acculturation into behaviors displayed in daily life. The results of character education cannot be obtained instantly. The character that has been realized now is probably the result of previous character education. If the evaluation of the character implanted in students is evaluated at that time it is also possible that it has not yet described the actual character education results. Current character education is expected to be a daily behavior the following year. Character education evaluation after new learning illustrates aspects of knowledge about characters only. The benefits of cooperative learning for low academic students are to increase the time spent on assignments, reduce disturbing behaviors, reduce individual conflicts, increase understanding, motivation, sensitivity, tolerance and kindness. The psychological impact of cooperative learning can increase self-esteem, social support and motivation and psychological adjustment to be positive (Santyasa, 2017).

Girmen \& Kaya (2019) in a classroom action research with 23 respondents found that the flipped classroom model can improve students' abilities such as language, cognitive, emotional, social and psychomotor abilities. Other strategies can be done by integrating existing local community wisdom values and developing local wisdom that is full of great values into learning strategies that will enhance the positive character of students (Parwati et al., 2018). Lickona (1991) states that in lectures at Harvard universities mentioned characters are higher than intelligence. Success will be in vain without character qualities such as honesty, sense of responsibility, kindness, and perseverance in the face of difficulties. Character values are also shown in the ethics of nursing education (Karim et al., 2018). 
Ethical values in nursing education such as respect for others, wisdom, constructive relationships, fairness and commitment in nursing education are the main things in nursing education. Further stated that mutual respect between students and educators as a very important aspect. Integration of character values is not only the responsibility of religious education and civic education but all fields of study have the same responsibilities (Boozaripour et al 2017; Hamid et al., 2018).

\section{CONCLUSION}

The first hypothesis of the results showed that there were significant differences in learning achievement and student character between group learning discussion on flipped classroom and lecture with a significance value smaller than 0.05 . The second hypothesis of this study shows that there are significant differences in learning achievement between group learning discussion on flipped classroom and lecture. The third hypothesis of this study shows that there are differences in student character between group learning discussion flipped classroom with lecture. Learning through the group discussion flipped classroom is superior compared to the class lecture on improving learning achievement and improving student character. We found that $G D F C$ can arouse the interest and desire of nursing students to learn through learning media that have been given before learning begins, build a culture of learning in the form of personal and interpersonal contact between students and students, between groups with groups and between students and lecturers.

\section{REFERENCES}

Albalawi, A. S. (2018). The effect of using flipped classroom in teaching calculus on students $^{\text {ee }}$ achievement at University of Tabuk. International Journal of Research in Education and Science (IJRES), 4(1), 198-207. DOI:10.21890/ijres.383137.

Aly, A. (2017). Pengembangan pembelajaran karakter berbasis soft skills di perguruan tinggi. Ishraqi, 1(1), 40-51.

Ardiansyah, M. F., Yoto, \& Sumarli. (2017). Pengaruh model pembelajaran kolaboratif dan bakat mekanik terhadap prestasi belajar siswa program keahlian teknik kendaraan ringan pada mata pelajaran gambar teknik di SMK Negeri 6 Malang. Jurnal Pendidikan Profesional, 6(3), 443-452.

Aristina, T., Wardhaningsih, S., \& Affandi, M. (2018). Pengaruh pelatihan pendidikan karakter terhadap self confidence mahasiswa di Akademi Keperawatan "YKY" Yogyakarta. Journal of Health, 5(1), 12-15.

Bergmann, J., \& Sams, A. (2014). Flipping for mastery. Educational Leadership, 71(4), 24-29.

Bleske, B. E., Remington, T. L., Wells, T. D., Klein, K. C., Guthrie, S. K., Tingen, J. M., Marshall, P. D., \& Dorsch, M. P. (2016). A randomized crossover comparison of team-based learning and lecture format on learning outcomes. American Journal of Pharmaceutical Education, 80(7), 1-6. 
Boozaripour, M., Abbaszadeh, A., Shahriari, M., \& Borhani, F. (2017). Ethical values in nurse education perceived by students and educators. Nursing Ethic, 20(10), 1-11 Doi: 10.1177/0969733017707009.

Daud, S., Chaudhry, A. M., \& Ali, S. K. (2016). Lecture based versus peer assisted learning: quasi-experimental study to compare knowledge gain of fourth year medical students in community health and nutrition course. Res Dev Med Educ, 5(2), 62-68. doi: 10.15171/rdme.2016.013.

Dehghanzadeh, S., \& Jafaraghaie, F. (2018). Comparing the effects of traditional lecture and flipped classroom on nursing students' critical thinking disposition: A quasiexperimental study. Ynedt (2018), 1-21. doi:10.1016/j.nedt.2018.09.027.

Doshi, N. P. (2017). Effectiveness of team-based learning methodology in teaching transfusion medicine to medical undergraduates in third semester: A comparative study. Asian J Transfus Sci, 11, 87-94. DOI: 10.4103/ajts.AJTS_123_16.

Florence, W. M. F. (2018). A cross-sectional study: Collaborative learning approach enhances learning attitudes of undergraduate nursing students. GSTF Journal of Nursing and Health Care (JNHC), 5(1), 1-5.

Formica, S. P., Easley, J. L., \& Spraker, M. C. (2010). Transforming common-sense beliefs into Newtonian thinking through just-in- time teaching. Phys. Educ. Res. 6, 1-7. doi/10.1103/ PhysRevSTPER.6.020106.

Fulton, K. (2012). Upside down and inside out: Flip your classroom to improve student learning. Learning \& Leading with Technology, 39(8), 12-17.

Girmen, P., \& Kaya, M. F. (2019). Using the flipped classroom model in the development of basic language skills and enriching activities: Digital stories and games. International Journal of Instruction, 12(1), 555-572. https://doi.org/10.29333/iji.2019.12136a.

Hamdani. (2011). Strategi Belajar Mengajar. Bandung: Pustaka Setia.

Hamid, A., Jaenudin, R., \& Koryati, D. (2018). Analisis nilai-nilai karakter siswa pada pembelajaran ekonomi di SMA Negeri 2 tanjung raja. Jurnal Profit. 5(1), 1-17.

Huang, C. S. J., Su, A. Y. S., Yang, S. J. H., \& Liou, H. (2016). A collaborative digital pen learning approach to improving students' learning achievement and motivation in mathematics courses. Computers \& Education, 2016, 1-39. DOI 10.1016/j.compedu.2016.12.014.

Julia, \& Supriyadi, T. (2018). The implementation of character education at senior high $\begin{array}{lllll}\text { school. } \quad \text { WHS } & \text { of } & 00085 .\end{array}$ https://doi.org/10.1051/shsconf/20184200085

Karim, A. A., Abduh, A., Manda, D., \& Yunus, M. (2018). The effectivity of authentic assessment based character education evaluation model. TEM Journal 7(3), 495-500. https:// dx.doi.org/ 10.18421/TEM73-04. 
Khatiban, M., Falahan, S. N., Amini, R., Farahanchi, A., \& A Soltanian. (2018). Lecture-based versus problem based learning in ethics education among nursing students. Journals Sagepub, 20(10), 1-12. DOI 10.1177/ 0969733018767246.

Lickona, Thomas. (1991). Educating for character: How our school can teach respect and responsibility. New York, Toronto, London, Sydney, Aucland: Bantam books.

Lindberg, E. (2018). Lecturers' lived experiences of guiding reflective seminars during nursing education. Original Research. Nurse Education in Practice 31(2018), 165-170. https://doi.org/10.1016/j.nepr.2018. 06.005.

Liu, T. C., Lin, Y., Gao, Y., Yeh, S. C., \& Kalyuga, S. (2015). Does the redundancy effect exist in electronic slideshow assisted lecturing? Computers \& Education, 88(2015), 303-314.

Lei Li. (2015). A student-centered guest lecturing: A constructivism approach to promote student engagement. Journal of Instructional Pedagogies, 15(2015), 1-7.

Matthew, A., \& Butler, D. (2017). Narrative, machinima and cognitive realism: Constructing an authentic real-world learning experience for law students. Australasian Journal of Educational Technology, 33(1), 148-162.

Mazer, J. P., \& Hess, J. A. (2017). What is the place of lecture in higher education? Communication Education, 66(2), 236-255.

Meyer, K. R., \& Hun, S. K. (2017). The lost art of lecturing: cultivating student listening and notetaking. Communication Education, 66(2), 239-241.

Milman, N. (2012). The flipped classroom strategy: what is it and how can it be used? Distance Learning, 9(3), 85-87.

Muhammad, Z. (2018). Pengaruh metode pembelajaran kooperatif tipe jigsaw terhadap motivasi dan hasil belajar mahasiswa. Ejournal UMM, 9(1). 2086-3071.

Nouri, J. (2016). The flipped classroom: for active, effective and increased learningespecially for low achievers. International Journal of Educational Technology in Higher Education (2016) 13-33 DOI 10.1186/s41239-016-0032-z.

Noviyanti, M. (2011). Pengaruh motivasi dan keterampilan berkomunikasi terhadap prestasi belajar mahasiswa pada tutorial online berbasis pendekatan kontekstual pada matakuliah statistika pendidikan. Jurnal Pendidikan, 12(2), 80-88.

Ozdamli, F. \& Asiksoy, G. (2016). Flipped classroom approach. World Journal on Educational Technology: Current Issues. 8(2), 98-105.

Parwati N. N., Tegeh I. M., \& Mariawan I. M. (2018). Integrating the values of local wisdom into the learning model: building positive student character. Educational Communications and Technology: Issues and Innovations. Springer, Cham, 23, $297-$ 307. 
Peterson, D. J. (2016). The flipped classroom improves student achievement and course satisfaction in a statistics course: A quasi-experimental study. Teaching of Psychology, 43(1), 10-15. DOI: 10.1177/0098628315620063.

Pratama, P. Y. S., \& Wulanyani, N. M. S. (2018). Pengaruh kuantitas, kemampuan komunikasi interpersonal, dan perilaku altruisme anggota kelompok terhadap social loafing dalam proses diskusi kelompok di fakultas kedokteran universitas udayana. Jurnal Psikologi Udayana, 5(1), 197-206.

Samuelson, D. B., Divaris, K., \& Ingeborg, J. (2017). Benefits of case-based versus traditional lecture-based instruction in a preclinical removable prosthodontics course. Journal of Dental Education. 81(4). 387-394.

Santyasa, I W., Warpala, I. W. S., \& Tegeh, I. M. (2018). The effect of conceptual change model in the senior high school students' understanding and character in learning physics. SHS Web of Conferences 42, 00058. https://doi.org/10.1051/shsconf/20184200058.

Sirakaya, A., \& Ozdemir, S. (2018). The effect of a flipped classroom model on academic achievement, self-directed learning readiness, motivation and retention. Malaysian Online Journal of Educational Technology, 6(1).

Slavin, R. E., Hurley, E. A., \& Chamberlain, S. (2003). Cooperative learning and achievement: Theory and research. In G. E. Miller, \& W. M. Reynolds (Eds.), Handbook of psychology: Educational psychology, 7, (pp.177-198). Hoboken, NJ: Wiley.

Stenlund, T., Jönsson, F. U., \& Jonsson, B. (2016). Group discussions and test-enhanced learning: Individual learning outcomes and personality characteristics. Educational Psychology, 2016, 1-12. http://dx.doi.org/10.1080/01443410.2016. 1143087.

Syah, M. F. J., Huda, S., \& Budi, H. S. (2017). Factors affecting oral participation in lecturing process in prospective accounting teacher students. Dinamika Pendidikan, 12(1), 61-67. DOI: 10.15294/ dp.v12i1.10584.

Titsworth, B. S. (2001). Immediate and delayed effects of interest cues and engagement cues on students'affective learning. Communication Studies, 52(3), 169-179. doi: 101080/10510970109388552.

The Ministy of National Education (2010). Desain Induk Pendidikan Karakter (8-9). Jakarta

Triatmanto. (2010). Tantangan implementasi pendidikan karakter di sekolah. Cakrawala Pendidikan, Mei 2010, Th. XXIX, Edisi Khusus Dies Natalis UNY

Tyas, M. C. D. (2016). Modul bahan ajar cetak keperawatan kegawatdaruratan dan manajemen bencana. Pusdik SDM Kesehatan. Kementerian Kesehatan Republik Indonesia. From bppsdmk.kemkes.go.id//Keperawatan-gadar-dan-manajemen-B. 
Unal, Z., \& Unal, A. (2017). Comparison of Student Performance, Student Perception, and Teacher Satisfaction with Traditional versus Flipped Classroom Models. International Journal of Instruction, 10(4), 145-164. https://doi.org/10.12973/iji.2017.1049a.

Vela, J. C., Sparrow, G. S., Whittenberg, J. F., \& Rodriguez, B. (2018). The role of character strengths and importance of family on Mexican American college students'career decision self-efficacy. Journal of Employment Counseling, 55, 16-26. DOI: $10.1002 /$ joec. 12070 .

Wicaksono, A. G. (2016). Penguatan pendidikan karakter melalui pembelajaran ilmu alamiah dasar. Widya Wacana. 11(2), 116-121.

Widayanti, L., \& Hakim, H. (2017). Pembelajaran kooperatif tipe jigsaw sebagai upaya pendidikan karakter pada matakuliah operation research. Jurnal Matematika dan Pendidikan Matematika II (1), 78-89.

Wong, F. M. F. (2018). A phenomenological research study: Perspectives of student learning through small group work between undergraduate nursing students and educators. Nurse Education Today, 68(2018), 153-158. https://doi.org/ 10.1016/j.nedt.2018.06.013. 